\title{
Alteration of Gut Microbiota in Autism Spectrum Disorder: An Overview
}

\author{
Donghun $\mathrm{Oh}^{1,2,3}$ and Keun-Ah Cheon ${ }^{1,2,3}$ \\ ${ }^{1}$ Department of Psychiatry, Yonsei University College of Medicine, Seoul, Korea \\ ${ }^{2}$ Division of Child and Adolescent Psychiatry, Severance Children's Hospital, Seoul, Korea \\ ${ }^{3}$ Institute of Behavioral Science in Medicine, Yonsei University College of Medicine, Seoul, Korea
}

\begin{abstract}
The microbiota-gut-brain axis, which refers to the bidirectional communication pathway between gut bacteria and the central nervous system, has a profound effect on important brain processes, from the synthesis of neurotransmitters to the modulation of complex behaviors such as sociability and anxiety. Previous studies have revealed that the gut microbiota is potentially related to not only gastrointestinal disturbances, but also social impairment and repetitive behavior-core symptoms of autism spectrum disorder (ASD). Although studies have been conducted to characterize the microbial composition in patients with ASD, the results are heterogeneous. Nevertheless, it is clear that there is a difference in the composition of the gut microbiota between ASD and typically developed individuals, and animal studies have repeatedly suggested that the gut microbiota plays an important role in ASD pathophysiology. This possibility is supported by abnormalities in metabolites produced by the gut microbiota and the association between altered immune responses and the gut microbiota observed in ASD patients. Based on these findings, various attempts have been made to use the microbiota in ASD treatment. The results reported to date suggest that microbiota-based therapies may be effective for ASD, but largescale, well-designed studies are needed to confirm this.
\end{abstract}

Key Words: Gut Microbiota; Microbiota-gut-brain axis; Autism spectrum disorder.

Received: December 3, 2019 / Revision: March 25, 2020 / Accepted: April 16, 2020

Address for correspondence: Keun-Ah Cheon, Department of Psychiatry, Yonsei University College of Medicine, 50-1 Yonse-ro, Seodaemun-gu, Seoul 03722, Korea

Tel: +82-2-2228-1620, Fax: +82-2-313-0891, E-mail: kacheon@yuhs.ac

\section{INTRODUCTION}

The microbiome refers to a community of microbes and the collection of genes contained within these microbes. Microbial cells are as abundant as somatic cells and have many more genes than the human genome (1.3:1 cells, 100:1 genes) [1]. The microbiome is affected by several factors, including human genetics, immune responses, diet, antibiotics, body part, lifestyle, and geography [2]. The microbiome is also thought to control gastrointestinal (GI) physiology, metabolism, nutrition, brain function, immune function, and even behavior [3]. Furthermore, the human microbiome is known to be correlated with diseases including cancer, obesity, irritable bowel disease, arthritis, and various psychiatric and neurological conditions such as major depressive disorder, stroke, Parkinson's disease, Alzheimer's disease, and autism [4]. However, we do not yet understand how variations in the microbiome affect health and disease. Furthermore, the mechanism and ex-

This is an Open Access article distributed under the terms of the Creative Commons Attribution Non-Commercial License (https://creativecommons.org/licenses/by-nc/4.0) which permits unrestricted non-commercial use, distribution, and reproduction in any medium, provided the original work is properly cited. tent to which the gut microbiota and treatments based on the microbiome (prebiotic, probiotic, and dietary interventions) influence brain health and behavior are not yet clearly known [5]. The microbiota-gut-brain axis, which refers to the bidirectional communication pathway between gut bacteria and the central nervous system (CNS), has important effects on many processes in the brain. These processes include neuroinflammation; stress axes activation; neurotransmission; formation of the blood-brain-barrier; myelination; neurogenesis and microglia maturation; synthesis of neurotransmitters including gamma-amino-butyric acid (GABA), noradrenalin, and dopamine; and modulation of complex behaviors such as sociability and anxiety $[5,6]$.

Several studies have demonstrated that the gut microbiota actually affects the development of the nervous system. For example, one study showed that neurogenesis in the dorsal hippocampus of adult germ-free (GF) mice was higher than that in conventional mice [7]. These results are consistent with the findings that neurogenesis of the hippocampus and the number of monocytes are reduced in mice treated with antibiotics over a long period [8]. Additionally, the blood- 
brain barrier (BBB) is more permeable without the gut microbiota, allowing macromolecules to enter the brain. This has been reported to be the result of reduced expression of the proteins that comprise the tight junction of the brain endothelium. The reduced BBB permeability after re-colonization with gut microbiota is clear evidence that the gut microbiota is involved in brain development [9]. Thus, it is rational to suggest that gut bacteria play a role in neurological and psychiatric diseases such as autism spectrum disorder (ASD).

ASD constitutes a group of neurodevelopmental disorders, which is characterized by repetitive and stereotyped behavior, with impaired communication and social interaction [10]. ASD has a profound effect on the development of children and on society. In 2014, the overall prevalence of ASD was 16.8 per 1,000 children aged 8 years, and in boys the prevalence was much higher (26.6 per 1,000 children) than in girls (6.6 per 1,000 children) [11]. The current cost of supporting a child with ASD without intellectual impairment is $£ 0.92$ million in the United Kingdom and \$1.4 million in the United States. The main costs of caring for children with ASD are derived from their need for special education and treatment, as well as the resultant reduced parental productivity [12]. Accordingly, there have been a number of efforts to identify biomarkers associated with ASD, including those related to genetic causes, immune system abnormalities, inflammation, and exposure to environmental toxic substances. Despite growing evidence that endogenous markers are involved in the pathology of ASD, early detection of these disorders remains a major challenge [13]. In addition, there are currently no effective treatments for the core symptoms of ASD, including social skill deficits. Therefore, understanding the role of microbiota and modulating the microbiota-gut-brain axis could help identify new ways to treat ASD [14].

Indeed, studies suggesting a correlation between multiple aspects of ASD and gut microbiota have been reported. In this article, we reviewed the results of studies investigating changes in the gut microbiota and their role in ASD. Our aim was to assess the value of microbiota as a potential biomarker or therapeutic target for ASD.

\section{GI DISTURBANCE AS A COMMON COMORBIDITY OF ASD}

The theory of the connection between ASD and the gut microbiota originated from GI symptoms that are frequently identified early in children with ASD. The GI impairments that are commonly observed in patients with ASD [15] include overproduction of intestinal gasses/flatulence, bloating, abdominal pain, diarrhea, burping/belching, gastroesophageal reflux symptoms, and constipation [16]. Different studies have reported that the prevalence of GI disorders in individuals with ASD ranges from $9 \%$ to $84 \%$, depending on the assessment method, compared with $9 \%$ to $37 \%$ for children without ASD $[17,18]$. General GI symptoms are reported to be five times more common in children with ASD; abdominal pain is twice as frequent, and both constipation and diarrhea have a four times higher incidence than that observed in typically developing children. The subjective symptoms of GI disorders such as abdominal pain, heartburn, or nausea are very difficult to evaluate because the clinical manifestation of digestive tract diseases in children with ASD may differ from those in children with typical development [17]. Functional constipation is a frequent finding in individuals with ASD [19]. The prevalence of constipation in ASD ranges from $20 \%$ to $33.9 \%$ according to recent studies [20], with findings indicating that moderate to severe constipation is more frequent in individuals with autism than in controls (36\% vs. 10\%) [19].

Several studies have reported an association between GI disturbances and the behavioral phenotype of ASD. GI symptoms have been reported to have a high incidence and be strongly associated with the severity of ASD [21]. ASD patients with GI disturbances show severe social skill deficits and higher anxiety than those without GI disturbances [22]. Children with ASD with GI disturbances have also been reported to have frequent anger outbursts and aggressive behavior [23]. One study indicated that such aggressiveness in children with ASD could be another manifestation of the physical discomfort caused by GI disturbances [24].

\section{MECHANISM OF GI IMPAIRMENT AND THE GUT MICROBIOTA IN ASD}

The enteric nervous system (ENS) is a large and complex component of the autonomic nervous system and is uniquely equipped with internal microcircuits that can adjust GI function regardless of CNS input. Because the ENS and CNS share common neurotransmitters, signal pathways, and anatomical characteristics, the pathophysiological mechanisms underlying CNS disease are often associated with GI symptoms [25]. A genetic study reported that mutations in the chromodomain helicase DNA-binding protein 8 (CHD8) gene are associated with a genetically defined ASD subtype. ASD patients with CHD8 mutations are typified by macrocephaly, distinct faces, and GI complaints due to slow transit constipation. Disruption of the zebrafish CHD8 orthologue recapitulates features of the human phenotype, including expansion of the forebrain/midbrain and impairment of GI motility due to a reduction in postmitotic enteric neurons [26]. Pitt-Hopkins syndrome, another subtype of ASD, results 
from haploinsufficiency of the transcription factor 4 gene, and patients often suffer from constipation and gastroesophageal reflux [27]. Similarly, another study showed that the autism-linked R451C mutation of the neuroligin-3 gene changes the ENS in mice [28]. Enteric glial cells (EGCs) are another population of cells in the ENS emerging as local GI regulators that participate in neuroprotection, gut motility, gut inflammation, intestinal epithelial barrier function, and synaptic neurotransmission regulation [29]. Grubišić and Parpura [30] reported that EGC-linked connexin 43 plays a role in the mechanism contributing to GI problems, based on the altered expression of astrocytic markers in patients with ASD. The underlying mechanism of these phenomena remains elusive, and further studies are warranted to elucidate the involvement of EGCs in the ASD process.

Another keyword describing GI symptoms seen in ASD patients is "inflammation." Although no consistent results have been obtained, some studies have reported changes in inflammation markers in ASD patients with GI symptoms. For example, the transcriptional profile of intestinal tissue from children with ASD was similar to that of patients with inflammatory bowel diseases such as ulcerative colitis and Crohn's disease [31]. In addition, infiltration of lymphocytes, eosinophils, and monocytes was observed in the intestinal tissues of ASD patients, similar to that in those with food allergies [32].

The "leaky gut" hypothesis is based on the idea that defects in intestinal epithelial barrier permeability lead to inappropriate signaling by luminal components including bacteria, environmental toxins, and even dietary macromolecules. Increasing intestinal permeability allows the metabolites secreted by bacteria to cross the barrier and enter the blood, and can affect the brain by promoting the secretion of cytokines and triggering an immune response [33]. Inflammatory cytokines released by immune activation affect the CNS and interfere with normal neural development early in life, which can lead to ASD. Compared to children with typical development, one study found astrocyte overactivation and increased levels of pro-inflammatory cytokines in the cerebrospinal fluid (CSF) of children with ASD [34]. Another study showed that plasma levels of cytokines, such as interleukin, tumor necrosis factor- $\alpha$ (TNF- $\alpha$ ), and transforming growth factor beta were increased in children with ASD. In particular, this altered immune profile was associated with the severity of behavioral problems in ASD $[35,36]$. These studies suggest that inflammatory processes derived from the intestines may play an important role in the neuronal development that is central to ASD, as well as in the GI symptoms.

The gut microbiota plays an important role in regulating epithelial integrity that affects intestinal permeabillty [37].
For example, decreased expression of barrier-forming proteins, and increased expression of pore-forming proteins in tight junctions of intestinal epithelium, have been shown to be associated with Lactobacillus $[23,38]$. In children with ASD, concentrations of zonulin, a gut permeability modulating protein, are higher than those in typically developed children, and increased zonulin levels are associated with the severity of behavioral symptoms in ASD [39]. It was also reported that the expression of zonulin was associated with specific strains of the gut microbiota, such as Faecalibacterium and Ruminococcaceae [40]. Taken together, the results suggest that the gut microbiota affects intestinal permeability, and that the triggered inflammatory processes contribute to the pathogenesis of ASD.

\section{CHANGES IN GUT MICROBIOTA COMPOSITION IN ASD}

Many cross-sectional studies have shown alterations in the composition of microbiota in ASD. Common findings in many studies include increased Firmicutes to Bacteroidetes ratio and a higher abundance of Clostridium in ASD. Metagenomic analysis carried out by Williams et al. [41] showed compositional dysbiosis manifests as a decrease in Bacteroidetes, an increase in the ratio of Firmicutes to Bacteroidetes, and an increase in Betaproteobacteria in ASD patients. Tomova et al. [42] reported that children with autism showed a significant increase in the Firmicutes to Bacteroidetes ratio and elevation of the amount of Lactobacillus spp. Strati et al. [43] revealed that a significant increase in the Firmicutes/Bacteroidetes ratio in ASD patients was associated with a decrease in Bacteroidetes. They also found a decrease in the abundance of Alistipes, Bilophila, and Veillonella, but a significant increase in the abundance of Collinsella, Corynebacterium, and Lactobacillus in the ASD group. In the case of Clostridium, more species of this genus were found in the feces of children with autism than in normal children, and counts were also higher in children with autism [44]. Clostridium boltae and cluster I and XI were found to be several times more abundant in children with autism than in normal children [45]. Recently, Alshammari et al. [46] revealed that the incidence of Clostridium perfringens was significantly higher in an ASD group than in a control group. However, these findings are not always consistent between studies. In contrast to the finding that the Firmicutes to Bacteroidetes ratio increased due to a reduction in Bacteroidetes, De Angelis et al. [47] found that levels of Bacteroidetes and some Alistipes and Akkermansia species were higher in children with ASD than in normal children.

In addition, heterogeneous results have been reported. Fae- 
calibacterium, Ruminococcus, and Bifidobacterium were relatively less abundant, whereas Caloramator, Sarcina, Sutterellaceae, and Enterobacteriaceae were more abundant in children with ASD than in normal children and children with Pervasive Developmental Disorder Not Otherwise Specified (PDD-NOS) [47]. Kang et al. [48] reported significantly lower abundances of the genera Prevotella, Coprococcus, and unclassified Veillonellaceae in samples from individuals with autism than in samples from neurotypical children. Increased Bacteroidaceae, Prevotellaceae, and Ruminococcaceae [49], and reduced Prevotella copri, Faecalibacterium prausnit$z i i$, and Haemophilus parainfluenzae [50] were also found in the ASD population.

There have been several studies using non-autistic siblings as controls. Tomova et al. [42] reported that Desulfovibrio, Bifidobacterium, and Clostridia were more abundant in the ASD group, while Lactobacillus was relatively abundant in siblings. Furthermore, regarding measurements of abundance of Bacteriodetes and Firmicutes, the sibling groups tended to fall somewhere between those of normal children with no family history of ASD and those of children with ASD. This finding suggests that the pattern of microbial composition can be an indicator of the disease burden of ASD. However, contradictory results have also been reported. Several studies have compared microbial composition between children with ASD and neurotypical siblings and revealed no difference between the two groups [51-53]. These results suggest that the microbial composition was formed only under the influence of shared environmental factors, including eating habits.

There have been associations between abundance of certain microbial strains and the severity of ASD symptoms reported. The level of Clostridium abundance has been correlated with the disease severity of ASD, as measured using the Childhood Autism Rating score [23], and children with ASD with more severe symptoms have been shown to have higher levels of Desulfovibrio and Clostridia than children with milder symptoms [42]. A recent study also revealed that abundance of Megamonas was positively correlated with Autism Behavior Checklist scores [54].

Intestinal tissue obtained through biopsy has been used to confirm the composition of microorganisms present in some cases. Williams et al. [55] found that the genus Sutterella, which is rare in normal individuals, was abundant in ileum and caecum tissues of ASD patients. Kushak et al. [56] compared microbial composition between ASD patients and normal groups using duodenal mucosa tissue. The Burkholderia genus was more abundant in ASD patients than in normal controls, while levels of bacteria belonging to the Neiserria genus were relatively low. No findings in these studies were found to be consistent with the results obtained from stool sample-based studies. This discrepancy may be because the stool sample reflects the microbial composition in the large intestine, while the duodenal mucosa reflects the microbial composition in the small intestine [57]. Given this discrepancy, some researchers argue that samples representing the entire population of bacteria in the gut are required for further study [58].

As mentioned above, there are several studies showing differences in the intestinal microbial composition between the normal population and ASD patients. However, most of the studies included only a small number of subjects, and variables such as diet were not thoroughly controlled for [59]. As a result, the pattern of microbial composition has not yet been established as an ASD endophenotype. Nevertheless, it is clear that changes in microbial composition occur in the gut of ASD patients. In particular, some studies have found a correlation between symptom severity and specific strains, suggesting that there may be a correlation between ASD development and the gut microbiota.

\section{ASSOCIATION BETWEEN THE GUT MICROBIOTA AND ASD-RELEVANT BEHAVIORS}

Animal-based research to date has helped us better understand the role gut microbiota plays in ASD (Table 1). Lack of social behavior, the most important feature of ASD, has been observed in mice with altered gut microbiota, including GF mice. GF mice show decreased propensity to interact with a novel partner versus a nonsocial object or familiar partner in the three-chambered sociability test, and they spend more time exploring an empty chamber than a chamber with a novel mouse [60]. Stilling et al. [61] reported that a group of GF mice showed significantly lower interaction with other mice than controls and post-weaning colonized mice. In the other study, GF mice were found to spend significantly more time sniffing and interacting with a novel stimulus, due to higher motor activity than that in conventionally raised mice [62]. The results of these studies seem contradictory, but the conclusions are similar in that the role of the gut microbiota in the development of social behavior is important. In addition, GF mice also show increased stereotyped selfgrooming behavior and mice with an altered gut microbiota display repetitive burying behavior, as measured by the marble-burying test [37,60]. In some studies, GF mice have exhibited increased locomotor activity, rearing behaviors [63], and decreased anxiety-like behavior $[62,64,65]$. Moreover, many of these ASD-like behaviors have been reversed upon colonization with the gut microbiota in healthy mice $[63,66]$. 
Table 1. Animal studies about Microbiota and ASD-like phenotypes

\begin{tabular}{|c|c|c|c|c|c|}
\hline Study & Country & Subject & Behavior & Group & Description \\
\hline $\begin{array}{l}\text { Sudo et al. } \\
\text { [158] }\end{array}$ & Japan & Mice & $\begin{array}{l}\text { Stress } \\
\text { response }\end{array}$ & $\begin{array}{l}\text { Germ free/ } \\
\text { Specific pathogen free/ } \\
\text { Gnotobiotic mice }\end{array}$ & $\begin{array}{l}\text { Germfree mice have elevated stress } \\
\text { response, reduced BDNF in cortex and } \\
\text { hippocampus. Germfree colonization } \\
\text { with Bifidobacterium infantis reversed } \\
\text { hypothalamic-pituitary-adrenal stress } \\
\text { response }\end{array}$ \\
\hline $\begin{array}{l}\text { Verdú et al. } \\
\text { [159] }\end{array}$ & Canada & Mice & $\begin{array}{l}\text { Visceral } \\
\text { hypersensitivity }\end{array}$ & $\begin{array}{l}\text { Groups treated with } \\
\text { Antibiotic and Lactobacillus } \\
\text { paracasei, Antibiotic or } \\
\text { Placebo (saline water) }\end{array}$ & $\begin{array}{l}\text { L. paracasei NCC2461 normalized } \\
\text { visceral sensitivity }\end{array}$ \\
\hline $\begin{array}{l}\text { Desbonnet } \\
\text { et al. [141] }\end{array}$ & Ireland & Rats & $\begin{array}{l}\text { Depression- } \\
\text { like behavior }\end{array}$ & $\begin{array}{l}\text { Groups treated with } \\
\text { Bifidobacteria } \\
\text { infantis or not }\end{array}$ & $\begin{array}{l}\text { Probiotic B. infantis treatment did not } \\
\text { change swimming, climbing, and } \\
\text { immobility but decreased IFN } \gamma \text {, } \\
\text { TNF } \alpha \text { and IL-6 cytokines }\end{array}$ \\
\hline $\begin{array}{l}\text { Desbonnet } \\
\text { et al. [142] }\end{array}$ & Ireland & Rats & $\begin{array}{l}\text { Depression- } \\
\text { like behavior }\end{array}$ & $\begin{array}{l}\text { Maternal separation stress } \\
\text { models treated with } B \text {. } \\
\text { infantis, citalopram or not }\end{array}$ & $\begin{array}{l}\text { Probiotic Bifidobacterium infantis } \\
\text { treatment in a maternal separation } \\
\text { stress model normalized IL-6 levels, } \\
\text { increased swim behavior and reduced } \\
\text { immobility in forced swim test, and } \\
\text { restored basal noradrenaline levels } \\
\text { in brainstem }\end{array}$ \\
\hline $\begin{array}{l}\text { McKernan } \\
\text { et al. [160] }\end{array}$ & Ireland & Rats & $\begin{array}{l}\text { Visceral } \\
\text { hypersensitivity }\end{array}$ & $\begin{array}{l}\text { Visceral normosensitive } \\
\text { (Sprague-Dawley) and } \\
\text { visceral hypersensitive } \\
\text { (Wistar-Kyoto) rat }\end{array}$ & $\begin{array}{l}\text { Probiotic Bifidobacterium infantis } 35624 \\
\text { reduces visceral pain }\end{array}$ \\
\hline $\begin{array}{l}\text { Bercik et al. } \\
\text { [161] }\end{array}$ & Canada & Mice & $\begin{array}{l}\text { Anxiety- } \\
\text { like behavior }\end{array}$ & $\begin{array}{l}\text { Uninfected control and } \\
\text { T muris-infected mice, } \\
\text { treated with placebo, } \\
\text { etanercept, budesonide, } \\
\text { and probiotics }\end{array}$ & $\begin{array}{l}\text { Colonic inflammation induced anxiety like } \\
\text { behavior, decreased hippocampal BDNF } \\
\text { mRNA, and increased circulating TNF- } \alpha \\
\text { and IFN } \gamma \text { Probiotic Bifidobacterium } \\
\text { longum restored behavior and BDNF }\end{array}$ \\
\hline $\begin{array}{l}\text { Messaoudi } \\
\text { et al. [145] }\end{array}$ & France & $\begin{array}{l}\text { Rats and } \\
\text { adults }\end{array}$ & $\begin{array}{l}\text { Anxiety, } \\
\text { depression, } \\
\text { and stress }\end{array}$ & $\begin{array}{l}\text { Groups treated with } \\
\text { probiotic preparation, } \\
\text { placebo ( } 0.5 \% \\
\text { methylcellulose } \\
\text { solution) and diazepam }\end{array}$ & $\begin{array}{l}\text { Probiotic (Lactobacillus helveticus and } \\
\text { Bifidobacterium longum) reduced } \\
\text { anxiety-like behavior in rats and reduced } \\
\text { psychological stress inpatients }\end{array}$ \\
\hline $\begin{array}{l}\text { Diaz Heijtz } \\
\text { et al. [63] }\end{array}$ & Sweden & Mice & $\begin{array}{l}\text { Motor activity } \\
\text { and anxiety- } \\
\text { like behavior }\end{array}$ & $\begin{array}{l}\text { Germ free/Specific } \\
\text { pathogen free }\end{array}$ & $\begin{array}{l}\text { Germ-free mice have increased motor } \\
\text { activity and decreased anxiety } \\
\text { Changes in PSD-95 and synaptophysin } \\
\text { expression in striatum }\end{array}$ \\
\hline $\begin{array}{l}\text { Bravo et al. } \\
\text { [162] }\end{array}$ & Canada & Mice & $\begin{array}{l}\text { Anxiety- and } \\
\text { depression-related } \\
\text { behaviors }\end{array}$ & $\begin{array}{l}\text { Lactobacillus rhamnosus } \\
\text { (JB-1)-fed mice } \\
\text { Broth-fed mice (control) }\end{array}$ & $\begin{array}{l}\text { Probiotic L. rhamnosus treatment of mice } \\
\text { in a stress model reduced stress and } \\
\text { increased GABA receptor expression in } \\
\text { prefrontal cortex. L. rhamnosus increased } \\
\text { cortical GABA (B 1 b) receptor expression, } \\
\text { decreased GABA (A } 2 \text { ) expression in } \\
\text { prefrontal cortex and amygdala, } \\
\text { but increased in hippocampus. } \\
\text { L.rhamnosus reduced stress, anxiety and } \\
\text { depression behavior }\end{array}$ \\
\hline
\end{tabular}


Table 1. Animal studies about Microbiota and ASD-like phenotypes (continued)

\begin{tabular}{|c|c|c|c|c|c|}
\hline Study & Country & Subject & Behavior & Group & Description \\
\hline $\begin{array}{l}\text { Bercik et al. } \\
\text { [163] }\end{array}$ & Canada & Mice & Anxiety-like behavior & $\begin{array}{l}\text { Dextran sodium sulfate } \\
\text { colitis with Bifidobacterium } \\
\text { longum or control medium }\end{array}$ & $\begin{array}{l}\text { Chemical colitis mouse model treated } \\
\text { with probiotic (B. longum) had normalized } \\
\text { anxiety like behavior. Chronic colitis model } \\
\text { has increased anxiety. B. longum normali } \\
\text { zed behavior, but no change in BDNF } \\
\text { expression }\end{array}$ \\
\hline $\begin{array}{l}\text { Hsiao et al. } \\
\text { [37] }\end{array}$ & USA & Mice & ASD-like behaviors & $\begin{array}{l}\text { MIA offspring treated } \\
\text { with vehicle or } \\
\text { Bacteroides fragilis }\end{array}$ & $\begin{array}{l}\text { MIA mice have decreased GI barrier, } \\
\text { increased IL-6, decreased cytokine/ } \\
\text { chemokine, and gut microbial dysbiosis, } \\
\text { and autism-related behaviors that were } \\
\text { restored following colonization with B.fragilis }\end{array}$ \\
\hline $\begin{array}{c}\text { Desbonnet } \\
\text { et al. [66] }\end{array}$ & Ireland & Mice & $\begin{array}{l}\text { Social preference } \\
\text { and repetitive } \\
\text { behaviors }\end{array}$ & $\begin{array}{l}\text { Germ free rearing } \\
\text { and germ-free } \\
\text { bacterial colonization } \\
\text { mice groups }\end{array}$ & $\begin{array}{l}\text { Germ free mice had deficits in social } \\
\text { avoidance, social novelty, social } \\
\text { investigation and also had increased } \\
\text { repetitive self-grooming }\end{array}$ \\
\hline $\begin{array}{r}\text { Buffington } \\
\text { et al. [67] }\end{array}$ & USA & Mice & Social behavior & $\begin{array}{l}\text { Maternal high fat diet } \\
\text { treated with Lactobacillus } \\
\text { reuteri or not }\end{array}$ & $\begin{array}{l}\text { Maternal high fat diet induced social } \\
\text { deficits in offspring are restored following } \\
\text { colonization with Lactobacillus reuteri }\end{array}$ \\
\hline $\begin{array}{l}\text { Sharon et al. } \\
\text { [68] }\end{array}$ & USA & Mice & $\begin{array}{l}\text { Social behavior } \\
\text { and repetitive } \\
\text { behaviors }\end{array}$ & $\begin{array}{l}\text { Mice colonized by feces } \\
\text { of human donors } \\
\text { with ASD or TD donor }\end{array}$ & $\begin{array}{l}\text { Mice with human ASD, but not TD } \\
\text { displayed ASD-like behaviors Extensive } \\
\text { alternative splicing of risk genes are } \\
\text { observed in brains of mice with ASD. } \\
\text { Metabolome analysis showed significant } \\
\text { differences between the two groups }\end{array}$ \\
\hline
\end{tabular}

ASD: autism spectrum disorder, BDNF: brain derived neurotrophic factor, TNF- $\alpha$ : tumor necrosis factor- $\alpha$, IL: interleukin , GABA: gamma-amino-butyric acid, MIA: maternal immune activation, GI: gastrointestinal, TD: typically developed

Hsiao et al. [37] reported that offspring from an immuneactivated mother showed changes in gut microbial composition. These offspring were found to not only have GI barrier defects, but also multiple ASD-related endophenotypes including impairments of social interaction and communication. Treatment with human commensal Bacteroides fragilis ameliorates many of these ASD-related behaviors. Buffington et al. [67] found that offspring from high-fat diet mother rats exhibited social skill deficits, which was associated with gut microbial dysbiosis. They concluded that abnormalities in the gut microbiota cause oxytocin deficiency, resulting in insufficient long-term potentiation (LTP) in the ventral tegmental area and defects in social behavior. Similar to the study of Hsiao et al. [37] this behavioral problem was restored by colonization with a single strain of bacteria, Lactobacillus reuteri.

A recent study conducted by Sharon et al. [68] showed that transplanting the gut microbiota from human donors with ASD into GF wild type mice induced behavioral deficits relevant to ASD. Mice colonized with samples of ASD donors displayed more repetitive behavior, less locomotion, and less communication than did mice colonized with samples of typically developed (TD) donors. The study also reported differ- ential gene expression profiles in the prefrontal cortex and striatum, which is known to mediate social behavior between mice with ASD microbiota and mice with microbiota of TD donors, due to extensive alternative splicing of risk genes in the brains of mice with ASD microbiota. As previous studies have shown that alternative splicing occurs in the brain of humans with ASD, these findings suggest that the gut microbiota plays an important role in the occurrence of ASD, via altering the pattern of brain development. Metagenomic analysis showed that mice with ASD microbiota were relatively deficient in 5-aminovaleric acid (5AV) and taurine. BTBR T+Itpr3tf/J mice showing ASD features ingested solutions containing 5AV and taurine, which resulted in an improvement in ASD-like behavior.

The amygdala, another key region involved in social interaction, has also been repeatedly reported to be affected by microbiota. Examination of the amygdala in GF mice, before and after colonization with microbiota, showed significant differences in gene expression, exon usage, and RNA editing [69]. This also revealed that different transcriptional processes are activated in response to social stimuli in control and GF mice [61]. 


\section{METABOLITES INDUCED BY THE GUT MICROBIOTA IN ASD}

The gut microbiota are known to modulate the CNS by transmitting molecular signals in a variety of ways [2]. Shortchain fatty acids (SCFA), representative signaling molecules, are the product of food fermentation by the gut microbiota $[70,71]$. SCFA affect the brain by passing through the BBB, entering the brain, and regulating the production of neurotransmitters such as serotonin and dopamine [47]. In addition, SCFA are known to be involved in immune action by regulating T-cell cytokine secretion [72]. In ASD patients, the total amount of SCFA is lower than in TD subjects, and the amount positively correlates with Faecalibacterium, Ruminococcus, and Bifidobacterium. Butyrate, in particular, shows a significant decrease, while propionate is found to be higher than in TD subjects [47]. Although propionate is known to prevent damage to the body from hypertension by inhibiting excessive activity of immune cells [73], elevated levels can have disruptive effects [74]. Case reports have shown that increased propionate blood levels can cause behavior problems similar to autism [75], and propionacemia has been identified in children with autism [76]. Propionate can act as a neurotoxin that inhibits the formation of Nicotinamide adenine dinucleotide (NADH). Since $\mathrm{NADH}$ is a major substrate of the electron transport chain, it eventually degrades the nervous system [77]. Indeed, male rats injected with propionate into their brains displayed behavioral problems such as social behavior impairments and neuroinflammatory responses similar to those seen in ASD [78]. Peripheral propionate injections in rats also induce anxiety-like behavior and impair social interaction [79]. In addition, propionate adminsistered prenatally by maternal injection of sodium propionate solution promotes several behavioral problems associated with ASD in offspring [80]. Patients with Rett syndrome, a representative genetic cause of ASD, also show higher propionate levels than normal subjects [81]. In addition, Clostridia species, previously mentioned to be more abundant in ASD patients, are known to be involved in the production of propionate [43].

Butyrate, on the other hand, is a major SCFA that has neuroprotective effects, and is the main source for energy metabolism in intestinal epithelial cells, especially colonocytes [82]. As the most potent promoter of intestinal regulatory $\mathrm{T}$ cells, it mediates the inflammatory response in the colon, and has the prophylactic and therapeutic potential to prevent ulcerative colitis and colorectal cancer [83]. It also prevents inflammatory reactions by regulating the production of antiinflammatory cytokines such as interleukin (IL)-10 [84]. The anti-inflammatory action of butyrate also occurs in the brain [85]. In fact, butyrate is known to attenuate the symptoms of some neurodegenerative diseases [86]. The role of butyrate in ASD has not been fully studied, but given its neuroprotective function, it is possible that reduced butyrate may affect the pathophysiology of ASD.

Lipopolysaccharide (LPS) is a type of endotoxin produced by gram-negative bacteria, which promotes the secretion of pro-inflammatory cytokines, nitric oxide, and eicosanoids [87]. It can induce disruption of the $\mathrm{BBB}$ and increase $\mathrm{BBB}$ permeability, allowing exotoxins such as metals to enter the brain, which eventually accumulate in the brain and promote inflammatory responses through the activation of microglia [88]. Some studies showed that prenatal exposure to LPS by gram-negative bacterial infection induces autism-like behaviors, including social skill deficits [89,90]. Custódio et al. [91] conducted a study to determine which behavioral problems are caused by LPS exposure during the neonatal period in mice. Male mice injected with LPS solution at postnatal days 5 and 7 exhibited anxiety-like and repetitive behaviors during tasks. LPS-challenged male mice also showed increased immune activity, as measured by levels of IL- 4 and IL- 6 in the prefrontal lobe, hippocampus, and hypothalamus. These findings suggest that ASD features may occur if an immune reaction is triggered by changes in the gut microbiota or bacterial infection early in life. Similarly, a recent study revealed that early life immune system activation triggered by LPS lead to increased social impairment and repetitive behavior in mice [92]. In both studies, these changes were prominent in male rats, consistent with male predominance in ASD prevalence.

$\mathrm{P}$-cresol is a substance formed by bacteria, which acts as a toxin in various metabolic processes in humans [47], and is associated with abnormalities in the nervous system, such as increased lipid peroxidation in the brain, decreased $\mathrm{Na}(+)-\mathrm{K}+$ ATPase activity, and inhibition of noradrenaline formation $[93,94]$. A representative bacterium known to form p-cresol is Clostridium difficile. C. difficile stimulates the expression of the enzyme $\mathrm{p}$-hydroxyphenylacetate ( $\mathrm{p}$ HPA) and consequently induces the fermentation of tyrosine for the formation of $\mathrm{p}$-cresol. Bacteria such as Clostridium scatologenes, Lactobacillus, and Pseudomonas contribute to the conversion of toluene to p-cresol [95], and this was found to be higher in fecal and urine samples of ASD patients than in normal subjects $[47,96,97]$. Considering that urinary p-cresol is correlated with the severity of autism symptoms [98], it is thought to contribute to the worsening of ASD symptoms and gut dysfunction [99].

In addition, some strains directly affect the brain by being involved in the formation of neurotransmitters. Serotonin is known to be involved in critical stages such as neuronal dif- 
ferentiation or migration, myelination, and synaptic formation during the development of the CNS [100]. Serotonin produced by enterochromaffin cells is stored in the epithelium and nerve cells of the intestinal barrier [101]. At this time, serotonin reuptake transporter regulates serotonin activity by transferring secreted serotonin within the synapse back into the cell. Male GF mice have a significant elevation of 5-hydroxytryptamine (5-HT) and 5-hydroxyindoleacetic acid levels (5-HIAA) in the hippocampus [64], which are the main metabolites of the tryptophan metabolic pathway [102]. Another study also found that GF mice had increased 5-HT levels in the hippocampus and increased tryptophan levels in the blood [103]. Given that ASD-relevant endophenotypes such as social skill deficits and cognitive rigidity have been found in rodents with deficits in the 5-HT system [104-106], serotonin may be a neurotransmitter that plays an important role in the pathophysiology of ASD. Indeed, it has been shown that hyperserotoninemia occurs in autism [107]. Data reported by neuroimaging and post-mortem studies also suggest abnormalities in the brain serotonergic system in ASD $[108,109]$. Clostridia species promote the conversion of tryptophan to 5-HT by increasing the mRNA levels of tryptophan hydroxylase 1 in endochromaffin cells [110]. Species involved in serotonin production include Peptostreptococcus russellii, Lactobacillus [111-113], Streptococcus, Escherichia and Enterococcus [114]. Considering this fact, the gut microbiota may be the link between ASD and serotonin abnormality that is not yet fully understood.

\section{ALTERED IMMUNE RESPONSE IN ASD AND THE GUT MICROBIOTA}

As mentioned earlier, abnormalities in various immune responses have been observed in ASD patients. In terms of neuroimmunity, extensive microglial activity was observed in the brain tissue of ASD patients, including cortical regions, white matter, and cerebellum [34]. It was also found that the density of reactive microglia was increased in the dorsolateral prefrontal cortex of ASD patients [115]. The increased expression of microglial marker genes including triggering receptor expressed on myeloid cells 2 (TREM2) and killer cell activating receptor-associated protein (DAP12/ $K A R A P)$ in the prefrontal cortex of ASD patients also suggests a dysfunction of neuroimmunity in ASD [116]. These neuroimmune abnormalities were also confirmed in animal models, especially in the maternal immune activation (MIA) model, which is known to be associated with the development of ASD $[117,118]$. When the maternal immune system was stimulated by the administration of LPS during the gestational period, changes in microglial receptor function, dysregulated immune response, and ASD-relevant behaviors were observed in male offspring mice [37,119].

Various systemic immune abnormalities have been also observed in ASD. Changes in this cytokine network have been reported in the CSF and post-mortem brain tissue of ASD patients [34]. In particular, recent studies support the possibility that abnormalities in pro-inflammatory cytokines, including IL- 6 and TNF- $\alpha$, may affect the development of ASD. IL-6 is a cytokine produced by microglia, astrocytes, and neurons, and is necessary for neuron survival. However, prolonged elevation of IL-6 levels may induce several pathologies in the brain [120]. One study found that overexpression of IL- 6 caused problems with adhesion and migration of neuronal cells, and eventually facilitated the formation of excitatory synapses [121]. Animal model studies have confirmed that these changes can lead to ASD-relevant behavior [122]. Conversely, administration of anti-inflammatory agents in autistic mice have been found to reduce IL- 6 levels, thereby reducing autism-like behavior [123]. TNF- $\alpha$ is a molecule that is involved in synaptic plasticity [124]. Long-term elevation of TNF- $\alpha$ is known to inhibit LTP of the synapse and induce the learning and memory problems that are observed in ASD [125]. The CSF to serum ratio of TNF- $\alpha$ is increased in ASD patients [126]. As a result of analyzing the brain tissue of ASD patients, it was confirmed that the level of TNF- $\alpha$ was higher than that in TD subjects, specifically in the frontal cortex [127]. In addition, several studies have reported elevation of IL-1 $\beta$ levels, another immunomodulatory molecule involved in the inhibition of LTP and the reduction of synaptic strength [128], in peripheral blood of ASD patients [129,130]. These findings in ASD patients suggest that neurotoxicity or inhibition of neurodevelopment caused by immune abnormalities could be key pathophysiologies of ASD.

Several studies have shown that immune system abnormalities in ASD patients are associated with the gut microbiota. Higher density and branching complexity of microglia in multiple brain regions were observed in GF mice than in mice raised in a specific pathogen free environment. Similar to GF mice, microglial density was increased in mice colonized with a less complex composition of the gut microbiota. GF mice with malformed microglia showed social avoidance and a reduced immune response against stimuli such as viral infection. In the same study, both microglia abnormalities and ASD-relevant behaviors were corrected after re-colonization of GF mice with the gut microbiota extracted from TD mice [131]. Specific bacterial species from the gut microbiota, such as Bacteroides fragilis and a Clostridia species, are known to modulate immune reaction by upregulating levels of IL10 -producing T regulatory cells [132]. Interaction between the 
gut microbiota and the immune system could be relevant to the immune dysregulation found in ASD. For example, regulatory T-cell and $\mathrm{T}$ helper cell abnormalities are observed in ASD patients [127]. Considering that the microbiota is involved in the differentiation of myeloid cells, the monocyte and macrophage abnormalities observed in peripheral blood of ASD patients are also thought to be related to the gut microbiota $[133,134]$.

MIA during pregnancy is considered to increase the risk for ASD [117,135]. As mentioned above, Hsiao et al. [37] revealed offspring from MIA mice displayed not only ASDrelevant features, such as anxiety-like behavior, stereotypy, and reduced sociability, but also dysbiosis of the gut microbiota. Moreover, MIA offspring showed a change in gut permeability when compared to control mice due to decreased expression of tight junction proteins, as well as the altered expression of cytokines such as IL-12. In this study, restoration of the gut microbiota by oral treatment with specific bacterial species not only corrected gut permeability, but also improved behavioral problems similar to ASD. A recent study found that less ASD-relevant behaviors were observed in offspring from MIA mice with preconception microbiota transplantation than in offspring born to conventional MIA mice. The authors found that changes in microbial composition caused changes in IL-17a secretion, and also confirmed that inhibition of IL-17a signaling could lead to amelioration of ASD phenotypes, such as social impairment [136]. Collectively, these findings clearly indicate that the gut microbiota contributes to the immunological abnormalities observed in ASD. Furthermore, there is a potential for the gut microbiota to act as a link between MIA and the pathogenesis of neurodevelopmental disorders, including ASD. Further studies are needed to investigate the effects of microbiota on the immune system in order to uncover the pathophysiology of ASD, which is still unclear.

\section{THERAPEUTIC APPROACHES VIA THE GUT MICROBIOTA FOR ASD}

Probiotics generally refers to a collection of living microorganisms known to provide health benefits by improving or restoring the composition of the intestinal microflora [137]. The mechanism is still unknown, but a predominant role of probiotics is to modulate the immune system [138]. For example, Lim et al. [139] found that certain strains of Weissella cibaria in kimchi improved the symptoms of atopic dermatitis by regulating the response of regulatory $\mathrm{T}$ cells. In addition, probiotics play a beneficial role in strengthening the barrier, participating in the formation of nutrients such as vitamins, and preventing the growth of pathogens $[33,137]$.
Various probiotics have been studied in neurological and psychiatric disorders, among which the most beneficial strains are Bifidobacterium and Lactobacillus [140]. Bifidobacterium infantis improved not only the behavioral deficit of rat pups separated from their mother, but also physiologic responses including normalizing IL-6 and tryptophan release $[141,142]$. Innately anxious male mice, which were fed with Bifidobacterium longum and Bifidobacterium breve, showed reduced anxiety in behavioral tasks such as the marble-burying test [143]. Janik et al. [144] used non-invasive magnetic resonance spectroscopy techniques to observe what happened in the brain of mice when Lactobacillus strains were administered. As a result, brain concentrations of biomarkers such as glutamate, $\mathrm{N}$-acetyl aspartate, and GABA were increased. In humans, urinary free cortisol was decreased with treatment by probiotics consisting of Lactobacillus helveticus and Bifidobacterium longum [145]. Lactobacillus casei Shirota improves stress-related GI symptoms and psychological distress [146]. As mentioned above, colonization with strains such as Lactobacillus reuteri and Bacteroides fragilis has been shown to improve the behavior of mice showing an ASD phenotype [37,67]. In addition to these findings, Grossi et al. [147] reported a case of an ASD child whose symptoms had been improved through the use of probiotics. The subject was a 12 year-old boy with ASD and severe cognitive disability. Taking probiotics containing Bifidobacterium breve, B. longum, $B$. infanti, Lactobacillus acidophilus, L. plantarum, L. paracasei, L. bulgaricus, and L. delbrueckii for 3 months led to better social affects, as measured by the Autism Diagnostic Observation Schedule. The improvement lasted up to 9 months after discontinuation of treatment. Niu et al. [148] applied a combination of applied behavior analysis (ABA) training and probiotic administration for 4 weeks in children with ASD. Although it was difficult to distinguish from the effects of $\mathrm{ABA}$, the results showed that the symptoms of ASD patients taking probiotics, as measured by the Autism Treatment Evaluation Checklist, improved. These findings suggest that probiotics could be used to treat ASD, even though it would be too premature to conclude this, due to several limitations.

Fecal microbiota transplantation (FMT) is being actively studied as a new treatment for many diseases in which the gut microbiota is known to contribute to pathophysiology. Unlike probiotics, which administer to some specific strains, FMT alters the composition of hundreds of strains through the transplantation of feces of healthy donors into the intestines of patient [149]. FMT is recognized as a standard treatment for repeated infection of Clostridium difficile [150], and has been studied as a treatment tool for various diseases such as ulcerative colitis [151], Crohn's disease [152], irritable bowel syndrome [153], and epilepsy [154]. Kang et 
al. [155] conducted a study to identify the therapeutic effect of FMT in 18 children with ASD. The treatment protocol was divided into four stages. Children were given vancomycin for two weeks and bowel cleansing prior to transplantation. Standardized Human Gut Microbiota was administered orally and rectally, with a high initial dose for 2 days and a lower maintenance oral dose, alongside a stomach acid suppressant, for 7-8 weeks. Symptoms, as rated by the Gastrointestinal Symptom Rating Scale, were an approximately $80 \%$ reduced at the end of treatment, and included significant improvements in constipation, diarrhea, and abdominal pain. Overall autism symptoms, as measured by Parental Global Impression III, were also improved, and the effect was maintained for 8 weeks after discontinuation of treatment. Bacterial changes after FMT include increased diversity and altered abundance of three genera, Bifidobacterium, Prevotella, and Desulfovibrio. Recently, the same authors published a follow-up study of 18 FMT patients, which showed improvement in symptoms as long as 2 years after the end of treatment [156]. Although the number of participants was small, these findings suggest that FMT can be a useful therapeutic tool for ASD. The use of whole feces can lead to transferring pathogens from the donor to the patient, causing an unexpected infection. Attempts are made to reduce the possibility of unexpected infections by screening donors using stringent criteria, but there are always risks [157].

\section{CONCLUSION}

The microbiota is considered to play an essential role in the development of the normal nervous system and maintenance of brain function. Considering the results of various animal studies and human studies, it is clear that ASD and the gut microbiota are closely related.

First, the incidence of GI disturbances is higher in ASD patients than in normal subjects [15]. The results of several studies show a positive correlation between the severity of GI symptoms and core symptoms of ASD including social skill deficits [21,22]. These results suggest that core symptoms and GI disturbances may share the same pathology. The gut microbiota is thought to contribute to this process by altering the integrity of barriers, increasing permeability, and consequently inducing inflammation.

Several studies have attempted to confirm changes in microbial compositions in the ASD population. As a result of these efforts, several common findings have emerged, including a reduction in overall microbial diversity, an increase in Firmicutes to Bacteroidetes ratio [41-43], and a relative abundance of Clostridium [44-46]. However, many of these studies have limitations. Despite the high likelihood of bias when considering the properties of the gut microbiota that are sensitive to diet, most researchers have not found a way to control the variables of diet. In addition, most studies were carried out with a relatively small number of subjects, making it difficult to generalize the results. Many studies adopted a cross-sectional design, which makes it difficult to determine the causal relationship between alteration of the gut microbiota and disease development or course [59]. Future work should focus on overcoming these limitations.

Animal studies provide relatively more information about the relationship between ASD and the gut microbiota. In particular, studies showed that behavior is normalized by re-colonization with specific strains in offspring mice with ASD phenotype, suggesting the possibility that the gut microbiota can be used therapeutically [37,67]. Moreover, recent studies have shown that mice transplanted with stools of ASD patients exhibit ASD-like behaviors accompanied by changes in gene expression in the brain, unlike mice transplanted with normal stools [68]. These findings bring us a step closer to understanding the role of the gut microbiota in the development of ASD, which has not been possible through human studies.

Several metabolites produced by the gut microbiota have also been studied. Overall SCFA levels in ASD patients are reduced, while propionate, which could act as an endotoxin, is increased [47]. Animal studies have shown that exposure to propionate and LPS may cause behavioral problems similar to ASD, and changes in immune activity $[78,91]$. Serotonin metabolic abnormalities have been observed in ASD patients [107-109], and there is a possibility that the gut microbiota may be involved in this process [110]. Continuing the search for metabolites will make it possible to identify the missing link between the gut microbiota and ASD.

Immune abnormalities have been considered to play an important role in the pathogenesis of ASD through several recent studies. In the brain tissue of ASD patients, changes in reactivity as well as morphological changes in microglia and astrocytes have been observed. In addition, alteration of various cytokine levels, including IL- 6 and TNF-a, has been also observed in ASD patients. It is possible that these abnormal immune responses interfere with brain functions such as learning and memory and contribute to the development of ASD. Several studies support the link between changes in the immune response and the gut microbiota in ASD. In particular, studies using the MIA mouse model confirmed that various deficits in the offspring of MIA mice, including ASD-relevant behaviors and changes in gut permeability, were improved through correction of the gut microbiota. These findings indicate that the interaction between micro- 
biota and the immune system may play an important role in the pathogenesis of ASD.

Based on the results of the studies mentioned, studies were conducted to confirm the effectiveness of the therapeutic tools using microbiota. There have been no large, well-designed studies as yet, but some of the findings provide us with a positive impression regarding the therapeutic use of microbiota. In particular, we should note that the results of the study showed that FMT improved the symptoms in 18 children with ASD $[155,156]$. However, it must be recognized that FMT also presents a concurrent risk of infection.

In conclusion, we suggest that the gut microbiota is deeply involved in the development of ASD. However, more research is needed to further explore the development of ASD based on the microbiota-gut-brain axis. Greater control over variables such as diet and drug use will be particularly important for reducing the possibility of bias in human studies. We hope that our review, which encompasses many studies conducted to date, will help guide the direction of future research.

\section{Acknowledgments}

None.

\section{Conflicts of Interest}

The authors have no potential conflicts of interest to disclose.

\section{Author Contributions}

Conceptualization: Donghun Oh, Keun-Ah Cheon. Data curation: Donghun Oh. Formal analysis: Donghun Oh. Investigation: Donghun Oh. Methodology: Donghun Oh. Project administration: Keun-Ah Cheon. Resources: Donghun Oh. Software: Donghun Oh. Supervision: Keun-Ah Cheon. Validation: Donghun Oh, Keun-Ah Cheon. Visualization: Donghun Oh. Writing_original draft: Donghun Oh. Writing-review \& editing: Keun-Ah Cheon.

\section{ORCID iDs}

Donghun Oh https://orcid.org/0000-0003-3824-4783

Keun-Ah Cheon https://orcid.org/0000-0001-7113-9286

\section{REFERENCES}

1) Gilbert JA, Blaser MJ, Caporaso JG, Jansson JK, Lynch SV, Knight R. Current understanding of the human microbiome. Nat Med 2018;24:392-400.

2) Sharon G, Sampson TR, Geschwind DH, Mazmanian SK. The central nervous system and the gut microbiome. Cell 2016;167:915-932.

3) Vuong HE, Hsiao EY. Emerging roles for the gut microbiome in autism spectrum disorder. Biol Psychiatry 2017;81:411-423.

4) Vasquez A. Biological plausibility of the gut-brain axis in autism. Ann N Y Acad Sci 2017;1408:5-6.

5) Sherwin E, Dinan TG, Cryan JF. Recent developments in understanding the role of the gut microbiota in brain health and disease. Ann N Y Acad Sci 2018;1420:5-25.

6) Fung TC, Olson CA, Hsiao EY. Interactions between the microbiota, immune and nervous systems in health and disease. Nat Neurosci 2017;20:145-155.

7) Ogbonnaya ES, Clarke G, Shanahan F, Dinan TG, Cryan JF, O'Leary OF. Adult hippocampal neurogenesis is regulated by the microbiome. Biol Psychiatry 2015;78:e7-e9.
8) Möhle L, Mattei D, Heimesaat MM, Bereswill S, Fischer A, Alutis M, et al. Ly6 $\mathrm{C}^{\text {hi }}$ monocytes provide a link between antibiotic-induced changes in gut microbiota and adult hippocampal neurogenesis. Cell Rep 2016;15:1945-1956.

9) Braniste V, Al-Asmakh M, Kowal C, Anuar F, Abbaspour A, Tóth M, et al. The gut microbiota influences blood-brain barrier permeability in mice. Sci Transl Med 2014;6:263ra158.

10) Li Q, Han Y, Dy ABC, Hagerman RJ. The gut microbiota and autism spectrum disorders. Front Cell Neurosci 2017;11:120.

11) Baio J, Wiggins L, Christensen DL, Maenner MJ, Daniels J, Warren $\mathrm{Z}$, et al. Prevalence of autism spectrum disorder among children aged 8 years - autism and developmental disabilities monitoring network, 11 sites, United States, 2014. MMWR Surveill Summ 2018;67:1-23.

12) Buescher AV, Cidav Z, Knapp M, Mandell DS. Costs of autism spectrum disorders in the United Kingdom and the United States. JAMA Pediatr 2014;168:721-728.

13) Fakhoury M. Autistic spectrum disorders: a review of clinical features, theories and diagnosis. Int J Dev Neurosci 2015;43:70-77.

14) Bik EM. The hoops, hopes, and hypes of human microbiome research. Yale J Biol Med 2016;89:363-373.

15) Buie T, Campbell DB, Fuchs GJ 3rd, Furuta GT, Levy J, Vandewater J, et al. Evaluation, diagnosis, and treatment of gastrointestinal disorders in individuals with ASDs: a consensus report. Pediatrics 2010;125 Suppl 1:S1-18.

16) Wasilewska J, Klukowski M. Gastrointestinal symptoms and autism spectrum disorder: links and risks-a possible new overlap syndrome. Pediatric Health Med Ther 2015;6:153-166.

17) McElhanon BO, McCracken C, Karpen S, Sharp WG. Gastrointestinal symptoms in autism spectrum disorder: a meta-analysis. Pediatrics 2014;133:872-883.

18) Niehus R, Lord C. Early medical history of children with autism spectrum disorders. J Dev Behav Pediatr 200;27(2 Suppl):S120S127.

19) Afzal N, Murch S, Thirrupathy K, Berger L, Fagbemi A, Heuschkel R. Constipation with acquired megarectum in children with autism. Pediatrics 2003;112:939-942.

20) Peeters B, Noens I, Philips EM, Kuppens S, Benninga MA. Autism spectrum disorders in children with functional defecation disorders. J Pediatr 2013;163:873-878.

21) Mayer EA, Padua D, Tillisch K. Altered brain-gut axis in autism: comorbidity or causative mechanisms? Bioessays 2014;36:933939.

22) Fulceri F, Morelli M, Santocchi E, Cena H, Del Bianco T, Narzisi A, et al. Gastrointestinal symptoms and behavioral problems in preschoolers with autism spectrum disorder. Dig Liver Dis 2016;48: 248-254.

23) Iovene MR, Bombace F, Maresca R, Sapone A, Iardino P, Picardi A, et al. Intestinal dysbiosis and yeast isolation in stool of subjects with autism spectrum disorders. Mycopathologia 2017;182: 349-363.

24) Ding HT, Taur Y, Walkup JT. Gut microbiota and autism: key concepts and findings. J Autism Dev Disord 2017;47:480-489.

25) Rao M, Gershon MD. The bowel and beyond: the enteric nervous system in neurological disorders. Nat Rev Gastroenterol Hepatol 2016;13:517-528.

26) Bernier R, Golzio C, Xiong B, Stessman HA, Coe BP, Penn O, et al. Disruptive CHD8 mutations define a subtype of autism early in development. Cell 2014;158:263-276.

27) Sweatt JD. Pitt-Hopkins syndrome: intellectual disability due to loss of TCF4-regulated gene transcription. Exp Mol Med 2013; 45:e21.

28) Hosie S, Ellis M, Swaminathan M, Ramalhosa F, Seger GO, Balasuriya GK, et al. Gastrointestinal dysfunction in patients and mice expressing the autism-associated $\mathrm{R} 451 \mathrm{C}$ mutation in neuroligin-3. Autism Res 2019;12:1043-1056. 
29) Sharkey KA. Emerging roles for enteric glia in gastrointestinal disorders. J Clin Invest 2015;125:918-925

30) Grubišić V, Parpura V. The second brain in autism spectrum disorder: could connexin 43 expressed in enteric glial cells play a role? Front Cell Neurosci 2015;9:242.

31) Walker SJ, Fortunato J, Gonzalez LG, Krigsman A. Identification of unique gene expression profile in children with regressive autism spectrum disorder (ASD) and ileocolitis. PLoS One 2013;8:e58058.

32) Navarro F, Liu Y, Rhoads JM. Can probiotics benefit children with autism spectrum disorders? World J Gastroenterol 2016;22:1009310102.

33) Santocchi E, Guiducci L, Fulceri F, Billeci L, Buzzigoli E, Apicella F, et al. Gut to brain interaction in autism spectrum disorders: a randomized controlled trial on the role of probiotics on clinical, biochemical and neurophysiological parameters. BMC Psychiatry 2016;16:183

34) Vargas DL, Nascimbene C, Krishnan C, Zimmerman AW, Pardo CA. Neuroglial activation and neuroinflammation in the brain of patients with autism. Ann Neurol 2005;57:67-81.

35) Ashwood P, Krakowiak P, Hertz-Picciotto I, Hansen R, Pessah I, Van de Water J. Elevated plasma cytokines in autism spectrum disorders provide evidence of immune dysfunction and are associated with impaired behavioral outcome. Brain Behav Immun 2011;25:40-45.

36) Onore C, Careaga M, Ashwood P. The role of immune dysfunction in the pathophysiology of autism. Brain Behav Immun 2012;26:383392.

37) Hsiao EY, McBride SW, Hsien S, Sharon G, Hyde ER, McCue T, et al. Microbiota modulate behavioral and physiological abnormalities associated with neurodevelopmental disorders. Cell 2013;155:14511463.

38) Fiorentino M, Sapone A, Senger S, Camhi SS, Kadzielski SM, Buie TM, et al. Blood-brain barrier and intestinal epithelial barrier alterations in autism spectrum disorders. Mol Autism 2016;7:49.

39) Esnafoglu E, Cirrık S, Ayyıldız SN, Erdil A, Ertürk EY, Daglı A, et al. Increased serum zonulin levels as an intestinal permeability marker in autistic subjects. J Pediatr 2017;188:240-244.

40) Mörkl S, Lackner S, Meinitzer A, Mangge H, Lehofer M, Halwachs B, et al. Gut microbiota, dietary intakes and intestinal permeability reflected by serum zonulin in women. Eur J Nutr 2018;57:29852997.

41) Williams BL, Hornig M, Buie T, Bauman ML, Cho Paik M, Wick I, et al. Impaired carbohydrate digestion and transport and mucosal dysbiosis in the intestines of children with autism and gastrointestinal disturbances. PLoS One 2011;6:e24585.

42) Tomova A, Husarova V, Lakatosova S, Bakos J, Vlkova B, Babinska K, et al. Gastrointestinal microbiota in children with autism in Slovakia. Physiol Behav 2015;138:179-187.

43) Strati F, Cavalieri D, Albanese D, De Felice C, Donati C, Hayek J, et al. New evidences on the altered gut microbiota in autism spectrum disorders. Microbiome 2017;5:24.

44) Finegold SM, Molitoris D, Song Y, Liu C, Vaisanen ML, Bolte E, et al. Gastrointestinal microflora studies in late-onset autism. Clin Infect Dis 2002;35:S6-S16.

45) Song Y, Liu C, Finegold SM. Real-time PCR quantitation of clostridia in feces of autistic children. Appl Environ Microbiol 2004; 70:6459-6465.

46) Alshammari MK, AlKhulaifi MM, Al Farraj DA, Somily AM, Albarrag AM. Incidence of Clostridium perfringens and its toxin genes in the gut of children with autism spectrum disorder. Anaerobe 2020;61:102114.

47) De Angelis M, Piccolo M, Vannini L, Siragusa S, De Giacomo A, Serrazzanetti DI, et al. Fecal microbiota and metabolome of children with autism and pervasive developmental disorder not otherwise specified. PLoS One 2013;8:e76993.

48) Kang DW, Park JG, Ilhan ZE, Wallstrom G, Labaer J, Adams JB, et al. Reduced incidence of Prevotella and other fermenters in intestinal microflora of autistic children. PLoS One 2013;8:e68322.

49) Rose DR, Yang H, Serena G, Sturgeon C, Ma B, Careaga M, et al. Differential immune responses and microbiota profiles in children with autism spectrum disorders and co-morbid gastrointestinal symptoms. Brain Behav Immun 2018;70:354-368.

50) Kang DW, Ilhan ZE, Isern NG, Hoyt DW, Howsmon DP, Shaffer M, et al. Differences in fecal microbial metabolites and microbiota of children with autism spectrum disorders. Anaerobe 2018;49:121131.

51) Parracho HM, Bingham MO, Gibson GR, McCartney AL. Differences between the gut microflora of children with autistic spectrum disorders and that of healthy children. J Med Microbiol 2005;54:987-991.

52) Wang L, Christophersen CT, Sorich MJ, Gerber JP, Angley MT, Conlon MA. Low relative abundances of the mucolytic bacterium Akkermansia muciniphila and Bifidobacterium spp. in feces of children with autism. Appl Environ Microbiol 2011;77:67186721.

53) Gondalia SV, Palombo EA, Knowles SR, Cox SB, Meyer D, Austin DW. Molecular characterisation of gastrointestinal microbiota of children with autism (with and without gastrointestinal dysfunction) and their neurotypical siblings. Autism Res 2012;5:419-427.

54) Zhao RH, Zheng PY, Liu SM, Tang YC, Li EY, Sun ZY, et al. [Correlation between gut microbiota and behavior symptoms in children with autism spectrum disorder]. Zhongguo Dang Dai Er Ke Za Zhi 2019;21:663-669.

55) Williams BL, Hornig M, Parekh T, Lipkin WI. Application of novel PCR-based methods for detection, quantitation, and phylogenetic characterization of Sutterella species in intestinal biopsy samples from children with autism and gastrointestinal disturbances. mBio 2012;3:e00261-11.

56) Kushak RI, Winter HS, Buie TM, Cox SB, Phillips CD, Ward NL. Analysis of the duodenal microbiome in autistic individuals: association with carbohydrate digestion. J Pediatr Gastroenterol Nutr 2017;64:e110-e116.

57) Kumar H, Lund R, Laiho A, Lundelin K, Ley RE, Isolauri E, et al. Gut microbiota as an epigenetic regulator: pilot study based on whole-genome methylation analysis. mBio 2014;5:e02113-14.

58) Srikantha P, Mohajeri MH. The possible role of the microbiotagut-brain-axis in autism spectrum disorder. Int J Mol Sci 2019;20:2115.

59) Cryan JF, O'Riordan KJ, Sandhu K, Peterson V, Dinan TG. The gut microbiome in neurological disorders. Lancet Neurol 2020;19:179-194.

60) Byrne CS, Chambers ES, Morrison DJ, Frost G. The role of short chain fatty acids in appetite regulation and energy homeostasis. Int J Obes (Lond) 2015;39:1331-1338.

61) Stilling RM, Moloney GM, Ryan FJ, Hoban AE, Bastiaanssen TF, Shanahan F, et al. Social interaction-induced activation of RNA splicing in the amygdala of microbiome-deficient mice. Elife 2018;7:e33070.

62) Arentsen T, Raith H, Qian Y, Forssberg H, Diaz Heijtz R. Host microbiota modulates development of social preference in mice. Microb Ecol Health Dis 2015;26:29719.

63) Diaz Heijtz R, Wang S, Anuar F, Qian Y, Björkholm B, Samuelsson A, et al. Normal gut microbiota modulates brain development and behavior. Proc Natl Acad Sci U S A 2011;108:3047-3052.

64) Clarke G, Grenham S, Scully P, Fitzgerald P, Moloney RD, Shanahan F, et al. The microbiome-gut-brain axis during early life regulates the hippocampal serotonergic system in a sex-dependent manner. Mol Psychiatry 2013;18:666-673.

65) McVey Neufeld KA, Perez-Burgos A, Mao YK, Bienenstock J, Kunze WA. The gut microbiome restores intrinsic and extrinsic nerve function in germ-free mice accompanied by changes in calbindin. Neurogastroenterol Motil 2015;27:627-636. 
66) Desbonnet L, Clarke G, Shanahan F, Dinan TG, Cryan JF. Microbiota is essential for social development in the mouse. Mol Psychiatry 2014;19:146-148.

67) Buffington SA, Di Prisco GV, Auchtung TA, Ajami NJ, Petrosino JF, Costa-Mattioli M. Microbial reconstitution reverses maternal diet-induced social and synaptic deficits in offspring. Cell 2016;165:1762-1775.

68) Sharon G, Cruz NJ, Kang DW, Gandal MJ, Wang B, Kim YM, et al. Human gut microbiota from autism spectrum disorder promote behavioral symptoms in mice. Cell 2019;177:1600-1618.e17.

69) Stilling RM, Ryan FJ, Hoban AE, Shanahan F, Clarke G, Claesson MJ, et al. Microbes \& neurodevelopment--Absence of microbiota during early life increases activity-related transcriptional pathways in the amygdala. Brain Behav Immun 2015;50:209-220.

70) Aw W, Fukuda S. Toward the comprehensive understanding of the gut ecosystem via metabolomics-based integrated omics approach. Semin Immunopathol 2015;37:5-16.

71) Lei E, Vacy K, Boon WC. Fatty acids and their therapeutic potential in neurological disorders. Neurochem Int 2016;95:75-84.

72) Rose S, Bennuri SC, Murray KF, Buie T, Winter H, Frye RE. Mitochondrial dysfunction in the gastrointestinal mucosa of children with autism: a blinded case-control study. PLoS One 2017;12: e0186377.

73) Cani PD, Knauf C. How gut microbes talk to organs: the role of endocrine and nervous routes. Mol Metab 2016;5:743-752.

74) Brestoff JR, Artis D. Commensal bacteria at the interface of host metabolism and the immune system. Nat Immunol 2013;14:676684.

75) Feliz B, Witt DR, Harris BT. Propionic acidemia: a neuropathology case report and review of prior cases. Arch Pathol Lab Med 2003; 127:e325-e328.

76) Al-Owain M, Colak D, Albakheet A, Al-Younes B, Al-Humaidi $\mathrm{Z}$, Al-Sayed M, et al. Clinical and biochemical features associated with BCS1L mutation. J Inherit Metab Dis 2013;36:813-820.

77) Frye RE, Rose S, Chacko J, Wynne R, Bennuri SC, Slattery JC, et al. Modulation of mitochondrial function by the microbiome metabolite propionic acid in autism and control cell lines. Transl Psychiatry 2016;6:e927.

78) Shultz SR, MacFabe DF, Ossenkopp KP, Scratch S, Whelan J, Taylor $\mathbf{R}$, et al. Intracerebroventricular injection of propionic acid, an enteric bacterial metabolic end-product, impairs social behavior in the rat: implications for an animal model of autism. Neuropharmacology 2008;54:901-911.

79) Ossenkopp KP, Foley KA, Gibson J, Fudge MA, Kavaliers M, Cain DP, et al. Systemic treatment with the enteric bacterial fermentation product, propionic acid, produces both conditioned taste avoidance and conditioned place avoidance in rats. Behav Brain Res 2012;227:134-141.

80) Foley KA, Ossenkopp KP, Kavaliers M, Macfabe DF. Pre- and neonatal exposure to lipopolysaccharide or the enteric metabolite, propionic acid, alters development and behavior in adolescent rats in a sexually dimorphic manner. PLoS One 2014;9:e87072.

81) Borghi E, Borgo F, Severgnini M, Savini MN, Casiraghi MC, Vignoli A. Rett syndrome: a focus on gut microbiota. Int J Mol Sci 2017;18:344.

82) Den Besten G, van Eunen K, Groen AK, Venema K, Reijngoud DJ, Bakker BM. The role of short-chain fatty acids in the interplay between diet, gut microbiota, and host energy metabolism. J Lipid Res 2013;54:2325-2340.

83) Hoeppli RE, Wu D, Cook L, Levings MK. The environment of regulatory $\mathrm{T}$ cell biology: cytokines, metabolites, and the microbiome. Front Immunol 2015;6:61.

84) Wang G. Human antimicrobial peptides and proteins. Pharmaceuticals (Basel) 2014;7:545-594.

85) Offermanns S, Schwaninger M. Nutritional or pharmacological activation of $\mathrm{HCA}_{2}$ ameliorates neuroinflammation. Trends Mol
Med 2015;21:245-255.

86) Mohajeri MH, La Fata G, Steinert RE, Weber P. Relationship between the gut microbiome and brain function. Nutr Rev 2018;76: 481-496.

87) Abbas AK, Lichtman AH. Basic immunology: functions and disorders of the immune system. Philadelphia: Elsevier Health Scinces Division;2014.

88) Banks WA, Gray AM, Erickson MA, Salameh TS, Damodarasamy M, Sheibani N, et al. Lipopolysaccharide-induced blood-brain barrier disruption: roles of cyclooxygenase, oxidative stress, neuroinflammation, and elements of the neurovascular unit. J Neuroinflammation 2015;12:223.

89) Kirsten TB, Taricano M, Maiorka PC, Palermo-Neto J, Bernardi MM. Prenatal lipopolysaccharide reduces social behavior in male offspring. Neuroimmunomodulation 2010;17:240-251.

90) Kirsten TB, Chaves-Kirsten GP, Chaible LM, Silva AC, Martins DO, Britto LR, et al. Hypoactivity of the central dopaminergic system and autistic-like behavior induced by a single early prenatal exposure to lipopolysaccharide. J Neurosci Res 2012;90:1903-1912.

91) Custódio CS, Mello BSF, Filho AJMC, de Carvalho Lima CN, Cordeiro RC, Miyajima F, et al. Neonatal immune challenge with lipopolysaccharide triggers long-lasting sex- and age-related behavioral and immune/neurotrophic alterations in mice: relevance to autism spectrum disorders. Mol Neurobiol 2018;55:3775-3788.

92) Carlezon WA Jr, Kim W, Missig G, Finger BC, Landino SM, Alexander AJ, et al. Maternal and early postnatal immune activation produce sex-specific effects on autism-like behaviors and neuroimmune function in mice. Sci Rep 2019;9:1-18.

93) Calderón-Guzmán D, Hernández-Islas JL, Espítia Vázquez IR, Barragán-Mejía G, Hernández-García E, Del Angel DS, et al. Effect of toluene and cresols on $\mathrm{Na}+, \mathrm{K}+-\mathrm{ATPase}$, and serotonin in rat brain. Regul Toxicol Pharmacol 2005;41:1-5.

94) Goodhart PJ, DeWolf WE Jr, Kruse LI. Mechanism-based inactivation of dopamine beta-hydroxylase by p-cresol and related alkylphenols. Biochemistry 1987;26:2576-2583.

95) Selmer T, Andrei PI. p-Hydroxyphenylacetate decarboxylase from Clostridium difficile. A novel glycyl radical enzyme catalysing the formation of $p$-cresol. Eur J Biochem 2001;268:13631372.

96) Gevi F, Zolla L, Gabriele S, Persico AM. Urinary metabolomics of young Italian autistic children supports abnormal tryptophan and purine metabolism. Mol Autism 2016;7:47.

97) Yang Y, Tian J, Yang B. Targeting gut microbiome: a novel and potential therapy for autism. Life Sci 2018;194:111-119.

98) Altieri L, Neri C, Sacco R, Curatolo P, Benvenuto A, Muratori F, et al. Urinary p-cresol is elevated in small children with severe autism spectrum disorder. Biomarkers 2011;16:252-260.

99) Persico AM, Napolioni V. Urinary $p$-cresol in autism spectrum disorder. Neurotoxicol Teratol 2013;36:82-90.

100) Homberg JR, Kolk SM, Schubert D. Editorial perspective of the research topic "deciphering serotonin's role in neurodevelopment." Front Cell Neurosci 2013;7:212.

101) Gershon MD. 5-Hydroxytryptamine (serotonin) in the gastrointestinal tract. Curr Opin Endocrinol Diabetes Obes 2013;20:14-21.

102) Aymard N, Honore P, Carbuccia I. Determination of 5-hydroxytryptamine and tryptophan by liquid chromatography in whole blood. Its interest for the exploration of mental disorders. Prog Neuropsychopharmacol Biol Psychiatry 1994;18:77-86.

103) Borre YE, Moloney RD, Clarke G, Dinan TG, Cryan JF. The impact of microbiota on brain and behavior: mechanisms \& therapeutic potential. Adv Exp Med Biol 2014;817:373-403.

104) Kane MJ, Angoa-Peréz M, Briggs DI, Sykes CE, Francescutti DM, Rosenberg DR, et al. Mice genetically depleted of brain serotonin display social impairments, communication deficits and repetitive behaviors: possible relevance to autism. PLoS One 2012;7:e48975. 
105) Del'Guidice T, Lemay F, Lemasson M, Levasseur-Moreau J, Manta S, Etievant A, et al. Stimulation of $5-\mathrm{HT}_{2 \mathrm{C}}$ receptors improves cognitive deficits induced by human tryptophan hydroxylase 2 loss of function mutation. Neuropsychopharmacology 2014;39:1125-1134.

106) Mosienko V, Beis D, Pasqualetti M, Waider J, Matthes S, Qadri F, et al. Life without brain serotonin: reevaluation of serotonin function with mice deficient in brain serotonin synthesis. Behav Brain Res 2015;277:78-88.

107) Folk GE Jr, Long JP. Serotonin as a neurotransmitter: a review. Comp Biochem Physiol C 1988;91:251-257.

108) Goldberg J, Anderson GM, Zwaigenbaum L, Hall GB, Nahmias C, Thompson A, et al. Cortical serotonin type-2 receptor density in parents of children with autism spectrum disorders. J Autism Dev Disord 2009;39:97-104.

109) Oblak A, Gibbs TT, Blatt GJ. Reduced serotonin receptor subtypes in a limbic and a neocortical region in autism. Autism Res 2013;6:571-583.

110) Reigstad CS, Salmonson CE, Rainey JF 3rd, Szurszewski JH, Linden DR, Sonnenburg JL, et al. Gut microbes promote colonic serotonin production through an effect of short-chain fatty acids on enterochromaffin cells. FASEB J 2015;29:1395-1403.

111) Wlodarska M, Luo C, Kolde R, d'Hennezel E, Annand JW, Heim CE, et al. Indoleacrylic acid produced by commensal Peptostreptococcus species suppresses inflammation. Cell Host Microbe 2017;22:25-37.e6.

112) Lamas B, Richard ML, Leducq V, Pham HP, Michel ML, Da Costa G, et al. CARD9 impacts colitis by altering gut microbiota metabolism of tryptophan into aryl hydrocarbon receptor ligands. Nat Med 2016;22:598-605.

113) Zelante T, Iannitti RG, Cunha C, De Luca A, Giovannini G, Pieraccini G, et al. Tryptophan catabolites from microbiota engage aryl hydrocarbon receptor and balance mucosal reactivity via interleukin-22. Immunity 2013;39:372-385.

114) Dinan TG, Stilling RM, Stanton C, Cryan JF. Collective unconscious: how gut microbes shape human behavior. J Psychiatr Res 2015;63:1-9.

115) Morgan JT, Chana G, Pardo CA, Achim C, Semendeferi K, Buckwalter J, et al. Microglial activation and increased microglial density observed in the dorsolateral prefrontal cortex in autism. Biol Psychiatry 2010;68:368-376.

116) Edmonson C, Ziats MN, Rennert OM. Altered glial marker expression in autistic post-mortem prefrontal cortex and cerebellum. Mol Autism 2014;5:3.

117) Atladóttir HO, Thorsen P, Østergaard L, Schendel DE, Lemcke S, Abdallah M, et al. Maternal infection requiring hospitalization during pregnancy and autism spectrum disorders. J Autism Dev Disord 2010;40:1423-1430.

118) Malkova NV, Yu CZ, Hsiao EY, Moore MJ, Patterson PH. Maternal immune activation yields offspring displaying mouse versions of the three core symptoms of autism. Brain Behav Immun 2012;26:607-616.

119) Hsiao EY, McBride SW, Chow J, Mazmanian SK, Patterson PH. Modeling an autism risk factor in mice leads to permanent immune dysregulation. Proc Natl Acad Sci U S A 2012;109:1277612781.

120) Gruol DL. IL-6 regulation of synaptic function in the CNS. Neuropharmacology 2015;96:42-54.

121) Wei H, Zou H, Sheikh AM, Malik M, Dobkin C, Brown WT, et al. IL-6 is increased in the cerebellum of autistic brain and alters neural cell adhesion, migration and synaptic formation. J Neuroinflammation 2011;8:52.

122) Wei H, Chadman KK, McCloskey DP, Sheikh AM, Malik M, Brown WT, et al. Brain IL-6 elevation causes neuronal circuitry imbalances and mediates autism-like behaviors. Biochim Biophys Acta 2012;1822:831-842.
123) Kirsten TB, Casarin RC, Bernardi MM, Felicio LF. Pioglitazone abolishes autistic-like behaviors via the IL-6 pathway. PLoS One 2018;13:e197060.

124) Steinmetz CC, Turrigiano GG. Tumor necrosis factor- $\alpha$ signaling maintains the ability of cortical synapses to express synaptic scaling. J Neurosci 2010;30:14685-14690.

125) Cunningham AJ, Murray CA, O'neill LAJ, Lynch MA, O'connor JJ. Interleukin-1 $\beta$ (IL-1 $\beta$ ) and tumour necrosis factor (TNF) inhibit long-term potentiation in the rat dentate gyrus in vitro. Neurosci Lett 1996;203:17-20.

126) Chez MG, Dowling T, Patel PB, Khanna P, Kominsky M. Elevation of tumor necrosis factor-alpha in cerebrospinal fluid of autistic children. Pediatr Neurol 2007;36:361-365.

127) Li X, Chauhan A, Sheikh AM, Patil S, Chauhan V, Li XM, et al. Elevated immune response in the brain of autistic patients. J Neuroimmunol 2009;207:111-116.

128) Bellinger FP, Madamba S, Siggins GR. Interleukin 1 beta inhibits synaptic strength and long-term potentiation in the rat CA1 hippocampus. Brain Res 1993;628:227-234.

129) Ashwood P, Krakowiak P, Hertz-Picciotto I, Hansen R, Pessah IN, Van de Water J. Associations of impaired behaviors with elevated plasma chemokines in autism spectrum disorders. J Neuroimmunol 2011;232:196-199.

130) Ricci S, Businaro R, Ippoliti F, Lo Vasco VR, Massoni F, Onofri E, et al. Altered cytokine and BDNF levels in autism spectrum disorder. Neurotox Res 2013;24:491-501.

131) Erny D, Hrabě de Angelis AL, Jaitin D, Wieghofer P, Staszewski $O$, David E, et al. Host microbiota constantly control maturation and function of microglia in the CNS. Nat Neurosci 2015;18:965-977.

132) Round JL, Lee SM, Li J, Tran G, Jabri B, Chatila TA, et al. The Toll-like receptor 2 pathway establishes colonization by a commensal of the human microbiota. Science 2011;332:974-977.

133) Grigorenko EL, Han SS, Yrigollen CM, Leng L, Mizue Y, Anderson GM, et al. Macrophage migration inhibitory factor and autism spectrum disorders. Pediatrics 2008;122:e438-e445.

134) Hooper LV, Littman DR, Macpherson AJ. Interactions between the microbiota and the immune system. Science 2012;336:1268-1273.

135) Estes ML, McAllister AK. Maternal immune activation: Implications for neuropsychiatric disorders. Science 2016;353:772-777.

136) Lukens JR, Lammert CR, Frost EL, Bellinger CE. Critical roles for microbiota-mediated regulation of Th17 responses in a maternal immune activation model of autism. J Immunol 2018;200:166.36.

137) Sherwin E, Sandhu KV, Dinan TG, Cryan JF. May the force be with you: the light and dark sides of the microbiota-gut-brain axis in neuropsychiatry. CNS Drugs 2016;30:1019-1041.

138) Bermudez-Brito M, Plaza-Díaz J, Muñoz-Quezada S, GómezLlorente C, Gil A. Probiotic mechanisms of action. Ann Nutr Metab 2012;61:160-174.

139) Lim SK, Kwon MS, Lee J, Oh YJ, Jang JY, Lee JH, et al. Weissella cibaria WIKIM28 ameliorates atopic dermatitis-like skin lesions by inducing tolerogenic dendritic cells and regulatory $\mathrm{T}$ cells in BALB/c mice. Sci Rep 2017;7:40040.

140) Fond G, Boukouaci W, Chevalier G, Regnault A, Eberl G, Hamdani $\mathbf{N}$, et al. The "psychomicrobiotic": targeting microbiota in major psychiatric disorders: a systematic review. Pathol Biol (Paris) 2015;63:35-42.

141) Desbonnet L, Garrett L, Clarke G, Bienenstock J, Dinan TG. The probiotic Bifidobacteria infantis: An assessment of potential antidepressant properties in the rat. J Psychiatr Res 2008;43:164-174.

142) Desbonnet L, Garrett L, Clarke G, Kiely B, Cryan JF, Dinan TG. Effects of the probiotic Bifidobacterium infantis in the maternal separation model of depression. Neuroscience 2010;170:1179-1188.

143) Savignac HM, Kiely B, Dinan TG, Cryan JF. Bifidobacteria exert strain-specific effects on stress-related behavior and physiology in BALB/c mice. Neurogastroenterol Motil 2014;26:1615-1627.

144) Janik R, Thomason LAM, Stanisz AM, Forsythe P, Bienenstock J, 
Stanisz GJ. Magnetic resonance spectroscopy reveals oral Lactobacillus promotion of increases in brain GABA, N-acetyl aspartate and glutamate. Neuroimage 2016;125:988-995.

145) Messaoudi M, Lalonde R, Violle N, Javelot H, Desor D, Nejdi A, et al. Assessment of psychotropic-like properties of a probiotic formulation (Lactobacillus helveticus R0052 and Bifidobacterium longum R0175) in rats and human subjects. Br J Nutr 2011; 105:755-764.

146) Kato-Kataoka A, Nishida K, Takada M, Kawai M, Kikuchi-Hayakawa $\mathbf{H}$, Suda K, et al. Fermented milk containing Lactobacillus casei strain Shirota preserves the diversity of the gut microbiota and relieves abdominal dysfunction in healthy medical students exposed to academic stress. Appl Environ Microbiol 2016;82:3649-3658.

147) Grossi E, Melli S, Dunca D, Terruzzi V. Unexpected improvement in core autism spectrum disorder symptoms after long-term treatment with probiotics. SAGE Open Med Case Rep 2016;4: $2050313 X 16666231$

148) Niu M, Li Q, Zhang J, Wen F, Dang W, Duan G, et al. Characterization of intestinal microbiota and probiotics treatment in children with autism spectrum disorders in China. Front Neurol 2019;10:1084.

149) Vindigni SM, Surawicz CM. Fecal microbiota transplantation. Gastroenterol Clin North Am 2017;46:171-185.

150) Surawicz CM, Brandt LJ, Binion DG, Ananthakrishnan AN, Curry SR, Gilligan PH, et al. Guidelines for diagnosis, treatment, and prevention of Clostridium difficile infections. Am J Gastroenterol 2013;108:478-498.

151) Rossen NG, Fuentes S, van der Spek MJ, Tijssen JG, Hartman JH, Duflou A, et al. Findings from a randomized controlled trial of fecal transplantation for patients with ulcerative colitis. Gastroenterology 2015;149:110-118.e4.

152) Bak SH, Choi HH, Lee J, Kim MH, Lee YH, Kim JS, et al. Fecal microbiota transplantation for refractory Crohn's disease. Intest Res 2017;15:244-248.

153) Johnsen PH, Hilpüsch F, Cavanagh JP, Leikanger IS, Kolstad C, Valle PC, et al. Faecal microbiota transplantation versus placebo for moderate-to-severe irritable bowel syndrome: a double-blind, randomised, placebo-controlled, parallel-group, single-centre trial. Lancet Gastroenterol Hepatol 2018;3:17-24.

154) He Z, Cui BT, Zhang T, Li P, Long CY, Ji GZ, et al. Fecal microbiota transplantation cured epilepsy in a case with Crohn's disease: the first report. World J Gastroenterol 2017;23:3565-3568.

155) Kang DW, Adams JB, Gregory AC, Borody T, Chittick L, Fasano A, et al. Microbiota Transfer Therapy alters gut ecosystem and improves gastrointestinal and autism symptoms: an open-label study. Microbiome 2017;5:10.

156) Kang DW, Adams JB, Coleman DM, Pollard EL, Maldonado J, McDonough-Means S, et al. Long-term benefit of Microbiota Transfer Therapy on autism symptoms and gut microbiota. Sci Rep 2019;9:5821.

157) Petrof EO, Claud EC, Gloor GB, Allen-Vercoe E. Microbial ecosystems therapeutics: a new paradigm in medicine? Benef Microbes 2013;4:53-65.

158) Sudo N, Chida Y, Aiba Y, Sonoda J, Oyama N, Yu XN, et al. Postnatal microbial colonization programs the hypothalamic-pituitary-adrenal system for stress response in mice. J Physiol 2004;558:263-275.

159) Verdú EF, Bercik P, Verma-Gandhu M, Huang XX, Blennerhassett P, Jackson W, et al. Specific probiotic therapy attenuates antibiotic induced visceral hypersensitivity in mice. Gut 2006;55:182-190

160) McKernan DP, Fitzgerald P, Dinan TG, Cryan JF. The probiotic Bifidobacterium infantis 35624 displays visceral antinociceptive effects in the rat. Neurogastroenterol Motil 2010;22:1029-e268.

161) Bercik P, Verdu EF, Foster JA, Macri J, Potter M, Huang X, et al. Chronic gastrointestinal inflammation induces anxiety-like behavior and alters central nervous system biochemistry in mice. Gastroenterology 2010;139:2102-2112.e1.

162) Bravo JA, Forsythe P, Chew MV, Escaravage E, Savignac HM, Dinan TG, et al. Ingestion of Lactobacillus strain regulates emotional behavior and central GABA receptor expression in a mouse via the vagus nerve. Proc Natl Acad Sci U S A 2011;108:16050-16055.

163) Bercik P, Park AJ, Sinclair D, Khoshdel A, Lu J, Huang X, et al. The anxiolytic effect of Bifidobacterium longum NCC3001 involves vagal pathways for gut-brain communication. Neurogastroenterol Motil 2011;23:1132-1139. 